\title{
Identification of machinability of ceramic materials by turning
}

\author{
${ }^{1}$ Dana Stancekova, ${ }^{1}$ Tomas Kurnava, ${ }^{1}$ Michal Sajgalik, ${ }^{2}$ Natasa Naprstkova, ${ }^{1}$ Jozef Struharnansky, ${ }^{1}$ Peter Ščotka \\ ${ }^{1}$ University of Zilina, Faculty of Mechanical Engineering, Univerzitná 1, 010 26, Zilina, Slovak Republic. Email: \\ dana.stancekova@fstroj.uniza.sk, tomas.kurnava@fstroj.uniza.sk \\ ${ }^{2}$ Faculty of Production Technology and Management, JEPU in Ústí nad Labem, Czech Republic. E-mail: \\ naprstkova@fvtm.ujep.cz
}

Paper deals with the machining of super-hard ceramics by turning. The introductory part deals with analysis of used ceramic materials and their use in technical practice. Since it is a very hard technical ceramics and particularly resistant material, at present, is increasingly used to produce components that ensure long life and particularly high resistance, even in aggressive environments where metal materials can no longer be used. Products from ceramics are pressed and sintered directly to the desired shape, but in some cases they have to be machined, which technically can cause a problem. The aim of the experimental part is selection of suitable cutting insert, determining of cutting conditions that would ensure the productive machining of given ceramics. Work may serves as a troubleshooting support for machining ceramics.

Key words: Industrial ceramics, diamond cutting disc, super-hard materials.

\section{Acknowledgement}

The article was made under support grant project VEGA 1/0773/12 Implementation of technical ceramic material research to increase the innovation of hybrid products

\section{References}

[1] CEP, R., KOURIL, K., MRKVICA, I., JANASEK, I., PROCHAZKA, J. (2010) Zkoušky nastroju Kyocera v podminkach prerusovaneho rezu. In. Strojirenska technologie, vol. XV, 2010/3, pp. 51-58,

[2] CZAN, A., STEKLAC, D., STANCEKOVA, D. (2005). Tools for High Productive Machining of Bearing Materials By Turning. In Tools Zlin

[3] NOVÁKOVÁ, J., PETŘKOVSKÁ, L., BRYCHTA, J., STANČEKOVÁ, D. (2009). Influence of Cutting Parameters on Integrity Surface At High Speed Cuttin. In. Transactions of the V̌̌B - Technical University of Ostrava. Mechanical Series, ročník LV., číslo 1/2009, Česká republika. Ostrava: VŠB - TUO, pp. 203-209

[4] HOLESOVSKY F., NAPRSTKOVA N., NOVAK M. (2012). GICS for grinding process optimization. In Manufacturing Technology XII/12, UJEP: Ústi n. Labem. p. 22-26.

[5] http://www.matnet.sav.sk/index.php

[6] CZAN, A., TILlOVA, E., SEMCER, J., PILC, J. (2013) Surface and subsurface residual stresses after machining and their analysis by x-ray diffraction. In. Komunikacie, Volume 15, Issue 2, pp. 69-76

[7] CZÁN, A., SAJGALÍK, M., HOLUBJAK, J., KOURIL, K. (2013): Studying of cutting zone when finishing titanium alloy by application of multifunction measuring syste, In. Manufacturing Technology, 2013, Vol. 13, No. 4, pp. 428-431

[8] NÁPRSTKOVÁ, N., KUSMIERCZAK, S., CAIS, J. (2013): Influence of strontium in AlSi7Mg0.3 alloy on the tool wear, In. Manufacturing Technology, 2013, Vol. 13, No. 3, pp. 373-380,

[9] SAJGALIK, M., CZAN, A. (2011): Studying of processes in cutting zone by non-destructive methods, In Technological Engineering. volume 8, number 2

[10] KANDIL, F.A., LORD, J.D., FRY, A.T., GRANT, P.V. (2001) A Review of Residual Stress Measurement Methods-A Guide to Technique Selection, NPL Report MATC(A)04, pp. 25-32.

[11] PILC, J.- VASILKO, K.(2013) Development and applications of a rotating turning tool. In Manufacturing Technology XIII/13. UJEP: Ústi n. Labem. p. 226-231.

[12] SCHULZE V. - AUTENRIETH H. - DEUCHERT M. - WEULE H. (2010). Investigation of surface near residual stress states after micro-cutting by finite element simulation. In. CIRP Annals - Manufacturing Technology 59, pp. $117-120$

[13] www.sjf.tuke.sk 
[14] DANIŠOVÁ, N., RUŽAROVSKÝ, R., VELÍŠEK, K. (2011) Design alternatives of intelligent camera system for check parts at the intelligent manufacturing-assembly cell. In. ITMS 2011; Shanghai, Applied Mechanics and Materials, 7 Volume pp. 2262-2266

[15] KAROLCZAK, P. - KOWALSKI, M. - WAŚCIŃSKA, H. (2011) Wpływ minimalnego smarowania na chropowatość powierzchni po toczeniu materiałów kompo-zytowych o osnowie aluminium. In. Obróbka skrawaniem. Nauka a przemyst / pod red. Wita Grzesika. Opole, pp. 103-110

[16] HATALA M., CEP R., PANDILOV Z. (2010) Analysis of surface roughness and heat affected zone of surfaces of steel EN S355J0 after plasma arc cutting. In. Mechanical Engineering-Scientific Journal, University of Skopje, pp 1-6.

[17] LITVAJ, I., PONIŠČIAKOVÁ, O., STANČEKOVÁ, D., DRBÚL, M. (2013): Knowledge processes and their implementation in small transport companies, In: Transport means 2013 : proceedings of the 17th international konference, Kaunas University of Technology, Lithuania, pp. 153-156. 